\title{
Pelatihan Peningkatan Kompetensi Kader PKK Dalam Penggunaan Aplikasi Komputer Dengan Metode Andragogi RAMP 2 FAME di Kelurahan Rangkapan Jaya Baru
}

\author{
Reva Ragam Santika ${ }^{1)}$, Anita Diana ${ }^{2)}$ \\ ${ }^{12)}$ Universitas Budi Luhur, Jakarta, Indonesia
}

Corresponding Author: Reva Ragam Santika, reva.ragam@budiluhur.ac.id

\begin{abstract}
Abstrak: Pelatihan Komputer dengan menggunakan metode Andragogi RAMP 2 FAME (Recency, Appropriatenes, Motivation, Primacy, 2 Way Communication, Feedback, Active learning, Multi sense learning dan Exercise) bertujuan untuk memberikan pelatihan komputer Microsoft Word untuk pembuatan proposal dan laporan posyandu dimana metode ini mampu meningkatkan keterlibatan, tanggung jawab selama kegiatan pembelajaran serta umpan balik dari peserta sehingga tutor dapat mengetahui tingkat perubahan yang terjadi pada peserta pelatihan dimulai pada saat sebelum dan saat berlangsung kegiatan belajar. Pelatihan ini diikuti oleh 10 peserta kader PKK yang terdiri dari ibu ibu usia dewasa dan lanjut dari kelurahan Rangkapan Jaya Baru, setelah dilakukan pelatihan selama 6 jam, para kader PKK memiliki kemampuan untuk membuat cover yang menarik, membuat penomoran bab dan sub bab otomotis, penomoran halaman, table of content, table dan formatting table. Dari hasil kuesioner awal diketahui bahwa kompetensi awal para kader PKK dalam penggunaan aplikasi Microsoft Word untuk pembuatan proposal dan laporan yang sesuai dengan format data posyandu diketahui bahwa $60 \%$ kader PKK masih belum bisa memanfaatkan aplikasi Microsost Word untuk pembuatan proposal dan laporan sedangkan 40\% sudah dapat menggunakan Microsoft Word, setelah selesai pelatihan diperoleh hasil bahwa 50\% mengatakan mudah, 30\% sedang dan 20\% sulit dalam memanfaatkan Micosoft Word sebagai media pembuatan proposal dan laporan yang baik
\end{abstract}

Kata Kunci: Pelatihan Komputer, Andragogi, RAMP 2 FAME, Microsoft Word.

Abstract: Computer training using the RAMP 2 FAME Andragogy method (Recency, Appropriatenes, Motivation, Primacy, 2 Way Communication, Feedback, Active learning, Multi sense learning and Exercise) aims to provide Microsoft Word training to make proposals and posyandu reports where this method is capable to improve involvement, responsibility during learning activities as well as feedback from participants so that tutors can find out the level of change that occurs in students start from began and during learning activities. This training was attending by 10 PKK cadre participants consisting of adult and advanced mothers from the Rangkap Jaya Baru village, after 6 hours of training, PKK cadres had capability to make interesting covers, automatic chapter and sub-chapter numbering, page numbering, table of content, table and table formatting. From the results of the initial questionnaire it was known that the PKK cadres initial competence in using the Microsoft Word application for making proposals and reports in accordance with the posyandu data format was known that $60 \%$ of PKK cadres were still unable to use the Microsost Word application for making proposals and reports, and 40\% cadres were use Microsoft Word, after completed the training, the results showed that 50\% said it was easy, 30\% moderate and 20\% difficult to use Microsoft Word as a tool to make good proposals and reports

Keywords: Computer Training, Andragogy, RAMP 2 FAME, Microsoft Word.

Submitted: 12.01.2021, Revised: 29.03.2021, Accepted: 06.04.2021 


\section{Pendahuluan}

Gerakan PKK adalah gerakan nasional dalam pembangunan yang tumbuh dari, oleh dan untuk masyarakat untuk menciptakan keluarga yang beriman, bertaqwa pada Tuhan yang maha esa, dengan menjunjung tinggi akhlak mulia yang berbudi luhur, sehat sejahtera, lahir dan batin. (Depok, 2019), untuk mewujudkan nya dibutuhkan sebanyak mungkin kader-kader PKK yang bersedia dan mampu memberikan pencerahan kepada keluarga dan masyarakat agar pelaksanaan kegiatan pada hakikatnya dapat meningkatkan kualitas kegiatan masyarakat pada umumnya serta mewujudkan keluarga sejahtera pada khususnya. Gerakan PKK memiliki mekanisme yang bersifat hirarkis, koordinatif, konsultatif, universal dan independen dari pusat sampai ke kelurahan untuk mewujudkan nya maka dibutuhkan tim penggerak PKK kelurahan sebagai mitra kerja pemerintah kelurahan yang juga berperan sebagai perencana, pelaku dan pembina serta pengendali program PKK di tingkat Kelurahan dengan senantiasa mengusahakan memberikan yang terbaik untuk masyarakat juga sebagai motivator dan penggerak PKK di tingkat di bawah seperti kelompok PKK RW,RT,dan DasaWisma sehingga dapat mengelola dan melaksanakan kegiatan PKK secara mandiri dengan sebaik-baiknya. Agar dapat mencapai tujuan tersebut, para kader PKK perlu ditingkatkan kompetensi nya terutama dalam hal pemanfaatan teknologi karena sebagian besar kader PKK yang terdiri dari ibu-ibu yang tidak bekerja atau sebagian besar adalah ibu rumah tangga yang hanya memiliki latar belakang pendidikan lulusan SMA sehingga sebagian besar dari mereka masih tertinggal dalam hal penggunaan teknologi informasi seperti halnya dalam mengoperasikan Microsoft office.

Kondisi yang serupa juga dialami oleh PKK di Kelurahan Rangkapan Jaya Baru yang merupakan salah satu kelurahan yang berada di Kota Depok, Kecamatan Pancoran Mas, dengan luas wilayah 388,375 ha, kelurahan yang terdiri dari 15 Rukun Warga (RW) dan 98 rukun tetangga (RT), dengan jumlah keseluruhan jiwa sebanyak 39.763 yang terdiri dari laki-laki sebesar 20.219 jiwa dan perempuan 19.544 jiwa. Kelurahan Rangkapan Jaya baru menyadari bahwa pembangunan di kelurahan tersebut tidak lepas dari peran keluarga yang secara strategis membantu dalam mewujudkan keluarga sehat, sejahtera, maju dan mandiri. Sejak didirikan di tahun 1972, PKK membantu dalam memberdayakan keluarga terutama perempuan sebagai motor penggerak sebagai motivator dan dinamisator di masyarakat untuk mengembangkan partisipasi perempuan dalam pembangunan kelurahan melalui program-program yang dijalankan yang terdeskripsi secara jelas didalam 10 program PKK. Salah satu bentuk 10 program PKK adalah di bidang pelayanan kesehatan dasar di Posyandu sebagai bentuk upaya dalam meningkatkan layanan yang dibutuhkan oleh masyarakat seperti perbaikan gizi, Pendidikan dan perkembangan anak, peningkatan ekonomi keluarga, ketahanan pangan keluarga dan kesejahteraan sosial(Wanti and Tripustikasari, 2018). Akan tetapi dalam menjalankan layanan posyandu berdasarkan hasil wawancara dengan sekretaris tim penggerak PKK Kelurahan Rangkapan Jaya Baru bahwa kader PKK belum sepenuhnya mengenal dan mengetahui bagaimana cara menggunakan komputer, belum mahir dalam menggunakan perangkat lunak standar seperti Microsoft Word. Sedangkan kebutuhan untuk penguasaan dalam mengoperasikan komputer sangat tinggi untuk melakukan kegiatan administrasi dan pendataan kegiatan PKK serta masih kurangnya pengetahuan tentang menulis laporan yang baik dan benar sesuai dengan format data-data posyandu. Ketidak tersedianya tenaga pengajar yang memiliki kualifikasi untuk mengajari para Kader untuk lebih menguasai keterampilan komputer, dan juga usia para kader yang berada pada usia dewasa matang juga menjadi kendala dalam memahami dan menguasai penggunaan komputer.

Berdasarkan permasalahan diatas maka dapat diidentifikasikan bahwa permasalahan mitra terkait program pelatihan untuk membekali kompetensi anggota PKK dan kader Posyandu kelurahan rangkapan jaya baru adalah sebagai berikut: (1) Pelatihan Kompetensi 
Microsoft Office terutama terkait Microsoft Word, pelatihan Microsoft Word dibutuhkan oleh kader PKK dan kader Posyandu dalam memenuhi tugas rutin seperti pencatatan dan administrasi data (2) Belum tersedianya fasilitas untuk pelatihan kompetensi Microsoft Office terutama Microsoft Word. PKK dan Posyandu Rangkapan Baru jaya tidak memiliki fasilitas yang dapat membantu para kader untuk belajar seperti laboratorium komputer dan tidak semua kader memiliki fasilitas komputer atau laptop yang dapat mendukung mereka dalam meningkatkan keterampilan Microsoft Word, akibatnya pelatihan untuk peningkatan kompetensi yang terkait dengan komputer belum dapat dilaksanakan; (3) Belum tersedianya tenaga pengajar yang memiliki kualifikasi untuk memberikan pelatihan kompetensi Microsoft Office khususnya Microsoft Word. ketiadaan tenaga pengajar yang memiliki kualifikasi telah menghambat untuk terlaksananya pelatihan Microsoft Word (4) usia para kader PKK yang sebagian besar adalah orang dewasa dan usia lanjut membutuhkan waktu yang tidak sebentar dalam memahami dan menggunakan aplikasi Microsoft word terutama terkait Teknik-teknik untuk mendukung pembuatan laporan PKK.

Oleh karena itu untuk menjawab permasalahan tersebut maka Kelurahan Rangkapan Jaya Baru mengadakan kerjasama dengan Universitas Budi Luhur dengan memberikan beberapa solusi untuk membantu memecahkan permasalahan mitra, sebagai berikut: (1) Mengadakan pelatihan Microsoft Office terutama Microsoft Word yang berupa pelatihan yang difokuskan pada pelatihan, untuk meningkatkan kompetensi dalam pembuatan teknik - teknik dalam pembuatan laporan dengan menggunakan Microsoft Word (2) memfasilitasi para kader dengan meminjamkan beberapa laptop bagi para kader yang tidak memiliki laptop agar dapat mengikuti pelatihan Microsoft Word (3) Menyediakan tenaga pengajar yang berkompeten untuk pelaksanaan pelatihan Microsoft Office khususnya Microsoft Word yang terkait dengan pembuatan laporan. Tenaga pengajar yang berperan serta dalam pelatihan ini berjumlah dua orang dan untuk mendukung kegiatan pelatihan ini. (4) Menggunakan metode yang tepat untuk dapat membantu para kader untuk lebih cepat memahami materi yang disampaikan salah satu nya adalah Andragogi RAMP 2 FAME.

Pengabdian masyarakat terkait pelatihan Komputer sudah pernah diadakan oleh Hernawan berupa pelatihan komputer bagi perangkat desa di kecamatan Gondangrejo kabupaten Karanganyar. Pada pelatihan tersebut materi yang diberikan kepada perangkat desa seputar pengoperasian komputer mulai dari cara menghidupkan dan men shutdown komputer sampai dengan menjalankan program-program aplikasi yang ada di perangkat komputer (Sulistyanto, 2017). Pengabdian masyarakat serupa juga pernah dilakukan oleh Rahmawati dan Andika Rusli dengan sasaran pegawai KKN-PPM UKM di kota Palopo yang berupa pelatihan tentang tata cara pelatihan pembuatan dan pembimbingan laporan keuangan yang dimulai dengan pembuatan jurnal transaksi keuangan sampai dengan laporan akhir sesuai dengan bidang usaha yang ada pada UKM di kota Palopo (Rahmawati, 2017). Pengabdian di Desa Pong Lengor, Kecamatan Rahong Utara, Kabupaten Manggarai yang dilakukan oleh Yohannes Marryono Jamun berupa pelatihan keterampilan dasar komputer dan teknologi informasi kepada masyarakat Desa Pong Lengor, khususnya pemerintah atau perangkat desa untuk memberikan bekal bagi perangkat desa tentang manfaat komputer dan teknologi informasi (internet), terutama dalam hal pengembangan ilmu pengetahuan serta pemecahan masalah yang terkait dengan pekerjaan-pekerjaan administratif perangkat desa (Jamun, 2019)

Selanjutnya pengabdian masyarakat yang dilakukan oleh Linda Perdana Wanti dalam bidang teknologi informasi. Pada pengabdian kali ini memberikan pelatihan komputer dasar bagi kader PKK dan Posyandu Di Desa Patikraja dalam menggunakan program standar seperti microsoft powerpoint dan microsoft word untuk menunjang kinerja yang baik dan lancar dalam hal administrasi maupun pendataan (Wanti \& Tripustikasari, 2018). 
Terkait pemilihan metode yang tepat dalam penyampaian materi pelatihan berbasis komputer ini tentunya tidak bisa disamakan untuk semua tahapan umur, mengingat kader PKK sebagian besar adalah orang dewasa dan usia lanjut sehingga harus lebih dipahami apa yang menjadi pendorong bagi orang dewasa dan usia lanjut untuk belajar. Hambatan yang mungkin dihadapi terkait dengan apa yang diharapkan serta bagaimana dapat belajar dengan baik.

Oleh karena itu perlu adanya suatu metode untuk pembelajaran orang dewasa (andragogi) dan usia lanjut sebagai salah satu alternatif pemecahan bagi pelatihan , agar pelatihan tidak hanya sekadar sebagai upaya untuk mentransmisikan pengetahuan, tetapi dirumuskan sebagai suatu proses pendidikan sepanjang hayat (long life education) (Hiryanto, 2017)

Pelatihan ini tentunya berbeda dengan pelatihan Komputer yang pernah dilakukan oleh peneliti sebelumnya karena pelatihan ini menggunakan metode untuk membantu orang dewasa yang mengandung prinsip- prinsip pembelajaran untuk orang dewasa yaitu RAMP 2 FAME.

istilah RAMP 2 FAME yang berarti jalan kesuksesan yaitu Recency, Appropriatenes, Motivation, Primacy, 2 Way Communication, Feedback, Active learning, Multi sense learning dan Exercise yang mana prinsip-prinsip ini dapat memungkinkan pelatih untuk menyiapkan satu sesi secara tepat dan memadai sehingga penyajian sesi dapat dilakukan secara efektif dan efisien sehingga dapat membantu peserta pelatihan untuk memahami materi dengan baik(Windarto, 2017).

\section{Metodologi}

Metode dalam pengabdian masyarakat untuk para kader PKK Kelurahan rangkapan Jaya Baru Depok, dilkasanakan dengan tahapan sebagai berikut:

\section{A. Tahap Persiapan.}

Pada Tahapan ini mengadakan kunjungan kelokasi Mitra kemudian pihak Kelurahan menfasilitasi untuk mengadakan pertemuan dengan pengurus PKK. Dalam pertemuan tersebut dilakukan wawancara untuk menangkap permasalahan dan menentukan solusi yang tepat mengingat sebahagian besar dari para kader PKK belum memiliki keterampilan yang cukup baik serta sebagian besar para kader adalah orang dewasa dan usia lanjut sehingga membutuhkan metode khusus untuk penyampaian materi pelatihan.

\section{B. Tahap Penyampaian Usulan.}

Pada Tahapan ini, tim pengabdian masyarkat menyampaikan pengajuan materi yang akan disajikan. Materi dibuat menyesuaikan dengan permintaan dan kebutuhan pengurus PKK serta menentukan untuk waktu dan tempat pelaksanaa, serta menentukan berapa banyak peserta yang akan mengikuti pelatihan untuk menentukan berapa banyak laptop yang harus disediakan untuk mendukung pelatihan.

\section{Tahap Pelaksanaan} diskusi.

Pelaksanaan PKM ini menjadi tiga bagian yaitu kegiatan ceramah, praktek, dan kegiatan

1. Kegiatan Ceramah

Kegitan ini adalah kegiatan tahap awal yang berkaitan dengan Pelatihan Komputer dasar untuk membuat proposal dan laporan dengan menjelakan fungsi - fungsi di dalam Microsoft word yang dibutuhkan dalam membuat laporan sesuai dengan Format data posyandu serta melakukan Penyampaian Tujuan pembelajaran yang Relevansi dengan Pekerjaan. 


\section{Kegiatan Praktek}

Kegiatan ini adalah kegiatan inti yang berhubungan dengan pemahaman dan kemampuan mitra dalam proses pelatihan. Kegiatan ini meliputi praktek dan latihan dalam penggunaan fungsi - fungsi yang pakai dalam pembuatan proposal dan laporan. Kegiatan praktek meliputi: cover yang menarik, membuat penomoran bab dan sub bab otomotis, penomoran halaman, table of content, table and Formatting Table.

3. Kegiatan latihan meliputi: peserta membuat cover sesuai dengan format cover posyandu membuat penomoran bab dan sub bab otomotis, penomoran halaman, table of content, table and Formatting Table.

4. Kegiatan Diskusi

Kegiatan ini adalah kegiatan terakhir yang berhubungan dengan hasil praktek yang dilaksanakan bersama mitra.

Pelaksanaan PKM ini dikombinasikan dengan metode pembelajaran dewasa (andradogi) dengan menganut Prinsip RAMP 2 FAME yang dijabarkan sebagai berikut(Hani, 2016; Saladin, 2008) :

1. Recency $(\mathrm{R})$ : Bagian yang dipelajari paling terakhir adalah bagian yang paling mudah diingat peserta. Bahwa materi yang paling diingat peserta adalah yang paling terakhir dipelajari atau diterima pada saat terakhir. Di tahap ini tutor akan membuat ringkasan (summary) sesering mungkin dan memberikan catatan-catatan kunci/inti yang ditekankan di penghujung sesi.

2. Appropriateness (A): Semua metode, materi, alat bantu, dan bahan pelatihan harus menyesuaikan dengan kebutuhan peserta. Pada fase ini peserta dibantu untuk tetap mempertahankan motivasinya dan mengusahakan agar materi sesuai dengan kebutuhan peserta, serta menginformasikan kepada para peserta untuk mengerti keterkaitan antara informasi-informasi baru dengan pengetahuan yang sudah diperoleh peserta sebelumnya.

3. Motivation (M): peserta harus memiliki keinginan, kesiapan, dan punya alasan untuk belajar. Pada fase ini pelatih menciptakan lingkungan (atmosphere) belajar menjadi menyenangkan bagi para peserta dan juga pelatih itu sendiri.

4. Primacy (P): kesan pertama adalah hal yang mudah diingat dan dipelajari peserta. Pada Fase ini permulaan sesi adalah hal yang krusial, Sebagian besar peserta akan mendengarkan, maka harus dibuat semenarik mungkin dengan memberi muatan informasi-informasi penting ke dalamnya, Serta menunjukan bagaimana cara mengerjakan sesuatu yang harus ditunjukan dari awal dengan cara yang benar sejak dari awal.

5. 2-way communication (2): Proses belajar dalam pelatihan melibatkan komunikasi dengan peserta bukan kepada fasilitator Dalam fase ini harus terbentuk komuniksi 2 arah yang timbal balik dalam bentuk diskusi, yang memungkinkan terjadinya interaksi timbal balik di antara pelatih/fasilitator dan peserta/partisipan.

6. Feedback (F): Terdapat bentuk umpan balik antara fasilitator dan peserta untuk mewujudkan proses belajar yang efektif. Pada fase ini fasilitator harus memastikan bahwa peserta mengikuti dan menaruh perhatian pada apa yang disampaikan dan memberikan Umpan balik baik dalam positif maupun negative, memberikan apresiasi bagi peserta yang mampu mengerjakan atau menjawab pertanyaan dengan baik.

7. Active learning (A): Peserta akan belajar lebih cepat dan efektif jika mereka terlibat secara aktif dalam proses belajar itu sendiri. Orang dewasa umumnya tidak terbiasa seharian penuh duduk di ruangan kelas, berdasarkan hal ini maka konsep belajar aktif harus diterapkan secara konsisten agar peserta tidak merasa jenuh. 
8. Multiple-sense learning (M): kombinasi audiotori, visual dan kinesthetik merupakan modal untuk memaksimalkan hasil belajar karena proses belajar yang dengan melibatkan lebih dari satu indera akan lebih efektif daripada hanya melibatkan satu indera saja.

9. Exercise (E): Pengusaan terhadap suatu materi terkait denganapa saja yang sering dilatih dan dipelajari berulang kali secara teratur. Pada Fase ini memberikan latihan untuk mengulang materi pelatihan melalui pengulangan informasi dengan berbagai cara yang berbeda, karena semakin sering diulang maka semakin ingat informasi yang dberikan, karena biasanya peserta akan lupa 1/4 dari yang mereka pelajari dalam 6 jam dan 1/3 dalam 24 jam.

\section{Hasil dan Pembahasan}

\section{A. Hasil}

\section{Hasil Tahap Persiapan}

Pada tahap ini tim PKM melakukan koodinasi untuk melaukan persiapan pelatihan dengan Sekretaris penggerak PKK. Hasil kesepakatan bahwa pelaksanaan kegiatan pelatihan adalah tanggal 19 November 2020, dengan 15 peserta, kemudian dilanjutkan dengan koordinasi untuk penyusunan modul yang disesuaikan dengan kebutuhan peserta.

\section{Hasil Tahap Penyampaian Usulan}

Pada Tahapan ini pihak pengurus PKK menerima usulan materi yang disampaikan, materi disampaikan dalam bentuk cetakan komputer dan juga dalam bentuk PDF, materi disesuaikan dengan kebutuhan para pengurus PKK dalam meningkatkan kompetensi para kader dalam kegiatan pencatatan administrasi dan juga pembuatan laporan PKK.

\section{Hasil Tahap Pelaksanaan}

Kegiatan ini dilaksanakan sesuai dengan jadwal yang telah direncanakan. Jumlah peserta adalah 15 orang dan yang hadir hanya 10 peserta. Penyampaian materi pelatihan disampaikan oleh Reva Ragam Santika, M.Kom tentang Pelatihan Pembuatan Laporan PKK yang baik dan benar sesuai dengan format data-data posyandu, namun sebelumnya tim PKM mengukur terlebih dahulu penguasaan Microsoft Word sebagai sarana dalam pembuatan proposal dan laporan.

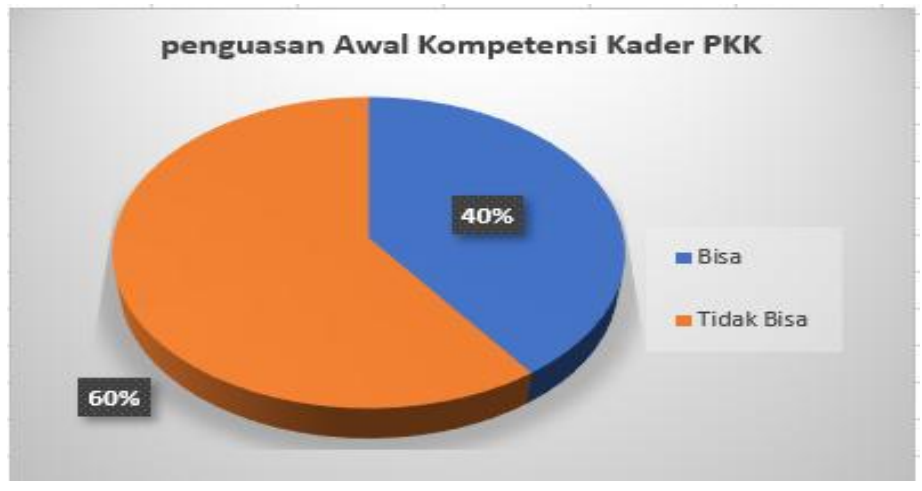

Gambar 1. Gambaran Penguasaan Awal Kompetensi Kader PKK 
Berdasarkan gambar 1 menunjukkan bahwa $60 \%$ belum dapat menggunakan aplikasi Microsoft Word untuk membuat Laporan yang baik dan benar sesuai dengan format data-data posyandu dan 40\% kader PKK mampu mengoperasikan aplikasi Microsoft Word. Karena program Microsoft Word ditujukan untuk penyusunan karya ilmiah, laporan makalah bahkan dapat digunakan untuk mendesain kartu (Nugraha, 2013)

Pelatihan Microsoft word, untuk para kader PKK banyak sekali memberi manfaat dalam menunjang kegiatan PKK seperti dalam pembuatan surat-menyurat, laporan sehingga para kader PKK menjadi lebih paham tentang penggunaan komputer dengan menggunakan aplikasi microsoft office, dalam pelatihan Microsoft word ini para kader PKK dibekali dengan bagaimana membuat laporan kegiatan yang benar mulai dari bagaimana membuat cover yang menarik, membuat penomoran bab dan sub bab otomotis, penomoran halaman, table of content, table and Formatting Table. Pelatihan dilaksanakan selama 6 Jam di ruangan rapat Kelurahan Rangkapan Jaya Baru. Pelaksanaan pelatihan berjalan dengan baik dan terlihat bahwa antusiasme peserta sangat tinggi. Setiap kali mengalami kesulitan dalam pelatihan, peserta langsung memberikan pertanyaan. Dari hasil pelatihan pengelolaan kelas yang telah dilaksanakan diperoleh hasil $50 \%$ mengatakan mudah, 30\% sedang dan 20\% sulit. Terlihat pada gambar 2 dibawah ini:

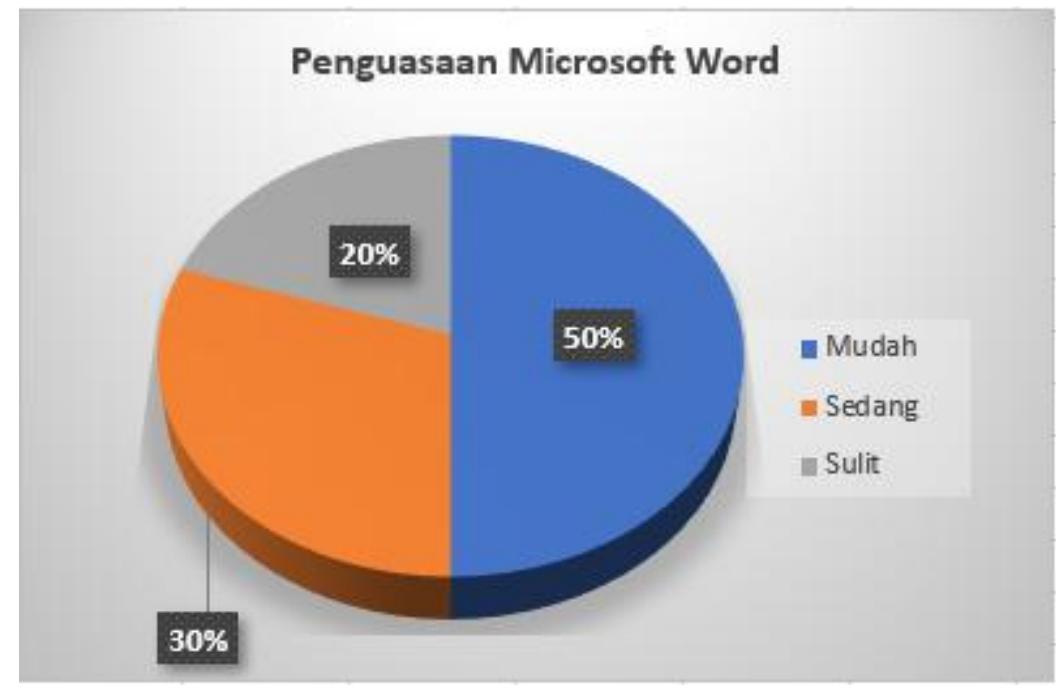

Gambar 2. Penguasaan Microsft word Pasca Pelatihan

Kesulitan yang dialami peserta selama pelatihan adalah sebagai berikut:

1. Membuat cover dengan mengimplementasikan perpanduan format object, karena penggunaan format object butuh keterampilan dalam penggunaan mouse mengubah titiktitik menjadi bentuk sesuai dengan keinginan

2. Membuat penomoran bab dan sub bab secara otomatis, karena pada bagian ini terdapat beberapa bagian yang harus diset. Pada bagian pengaturan ini terlihat masih banyak peserta yang masih bingung dengan tahapan di dalam pengaturan Penomoran Bab dan Sub bab secara otomatis. Akan tetapi itu semua dapat diatasi dengan pemberian langkah perlangkah sesuai dengan penomoran pada gambar jendela pengaturan penomoran Bab.

Dalam pelatihan ini, peserta mendapatkan pengetahuan tentang pengoperasian komputer termasuk mengoperasikan Microsoft Word dengan baik disamping itu juga Peserta memahami cara-cara menulis atau pendalaman materi tentang cara menulis sebuah laporan atau dokumentasi kegiatan dengan baik dan benar. Peserta atau kader PKK menjadi lebih handal 
dan terampil mengelola administrasi, terutama pembuatan laporan. Dan juga dapat bermanfaat pula untuk pembuatan dokumentasi kegiatan dari dalam dan di luar PKK Kelurahan

\section{B. Pembahasan}

Keseluruhan peserta yang mengikuti kegiatan pengabdian merupakan para kader PKK yang berprofesi sebagai ibu rumah tangga dan hampir sebagian besar nya merupakan orang tua/manula. Pelatihan ini berisikan pelatihan Microsoft Word dengan menggunakan metode pembelajaran yang dikhususkan bagi orang tua dan lanjut usia yaitu dengan menggunakan metode Andragogi dengan menerapkan prinsip RAMP 2 FAME ( Recency, Appropriateness, Motivation, Primacy, 2-way communication, feedback, Active learning, Multiple-sense learning, execise) dimana metode pembelajaran ini menggali minat, bakat dan kreativitas para kader PKK yang sebagian besar adalah orang tua/manula dengan cara persuasive dan menyenangkan, sehingga mampu menyeimbangkan kemampuan intelektualitas dengan kemampuan fisik serta kecerdasan spritual dan emosional para peserta.

Di dalam teknik pembelajaran ini dilakukan dengan mengedepankan sopan santun serta menjaga perasaan dari para peserta seperti tidak membantah, memotong, meragukan kemampuan individual, dan hal-hal lain yang mengakibatkan ketidaknyamanan para orang tua/manula. Serta memberikan pujian maupun memberikan apresiasi atas pernyataan maupun pertanyaan, memberikan kesimpulan yang baik dan benar, mengarahkan apabila diperlukan. Adapun strategi pembelajaran bagi usia lanjut adalah sebagai berikut:

1. Strategi melakukan pengelompokan kondisi individual sesuai dengan kemampuannya, baik secara intelektualitas serta kemampuan fisik.

2. Meningkat kan kepercayaan diri para orang tua/manula bahwa kompetensi mereka sangat dibutuhkan.

3. Pelaksanaan pembelajaran konstektual.

4. Menerima dan memediasi serta memfasilitasi berbagai kebutuhan, ide, pemikiran, gagasan serta kreativitas yang dimiliki oleh peserta.

Berikut ini adalah secara rinci metode dalam penyampaian materi tersebut dapat tergambar jelas dalam tabel berikut ini:

Tabel 1. Rangkaian Kegiatan Pelatihan

\begin{tabular}{|c|c|c|c|}
\hline No & Materi & Metode & Durasi \\
\hline 1. & $\begin{array}{l}\text { Penyampaian Tujuan pembelajaran } \\
\text { yang Relevansi dengan Pekerjaan } \\
\text { (Appropriateness, } \\
\text { Primacy) }\end{array}$ & Ceramah & 45 Menit \\
\hline 2. & $\begin{array}{lccc}\text { Pengenalan } & \text { Lingkungan } & \text { kerja } & \text { Dari } \\
\text { Microsoft } & \text { Word } & (2 & \text { way } \\
\text { Communication, Active Learning } & \\
\end{array}$ & Praktek & 45 menit \\
\hline 3 & $\begin{array}{l}\text { Praktek membuat Laporan PKK mulai } \\
\text { Dari Pembuatan cover smapai dengan } \\
\text { pembuatan Daftar Pustaka } \\
(2 \text { way Communication, Active } \\
\text { Learning, Multiple Sense learning) }\end{array}$ & Praktek & $2 \times 45$ menit \\
\hline 4 & $\begin{array}{l}\text { Latihan Membuat Laporan PKK } \\
(2 \text { way Communication, Active } \\
\text { Learning, Multiple Sense learning, } \\
\text { Exercise) }\end{array}$ & Praktek & $3 \times 45$ menit \\
\hline 5 & Evaluasi Hasil Pelatihan (Feedback) & $\begin{array}{c}\text { Diskusi dan tanya } \\
\text { Jawab } \\
\end{array}$ & 45 Menit \\
\hline
\end{tabular}


Keuntungan pelatihan dasar pembuatan proposal dan laporan kegiatan PKK dengan mengadosi metode Andragogi dengan mengadopsi prinsip RAMP 2 FAME adalah:

1. Terwujudnya keikutsertaan, tanggung jawab dan umpan balik dari peserta pelatihan.

2. Terbentuknya tanggung jawab dalam kegiatan pembelajaran. Tumbuhnya kesadaran peserta pelatihan tentang sejauh mana tanggung jawab mereka dalam kegiatan belajar.

3. Adanya umpan balik (feed back) dan peserta didik. Umpan balik ini bermanfaat bagi fasilitator untuk menangkap sebaik mungkin tingkat perubahan yang dialami oleh peserta didik pada saat sebelum dan pada saat kegiatan belajar sedang berlangsung.

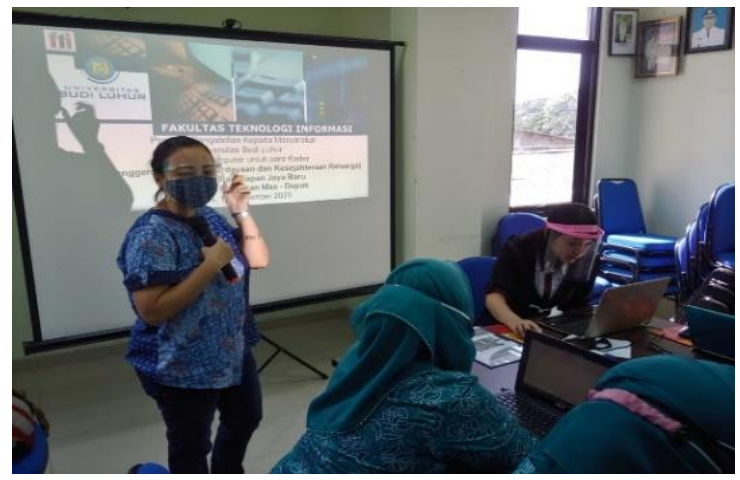

Gambar 3. Ceramah terkait pengenalan Dasar Komputer

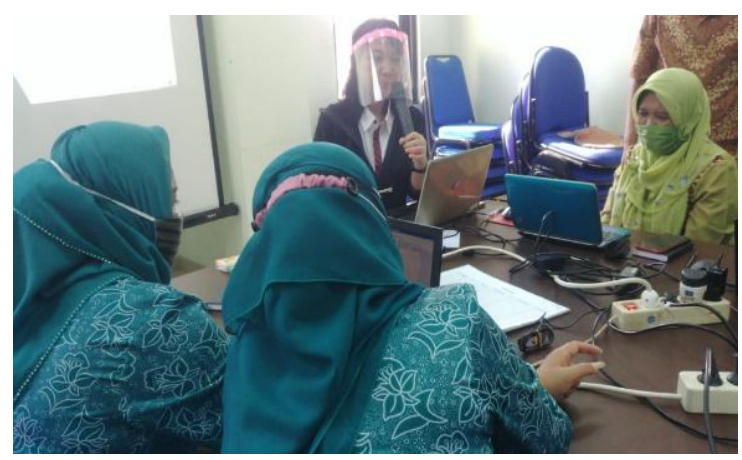

Gambar.4 Kegiatan Praktek

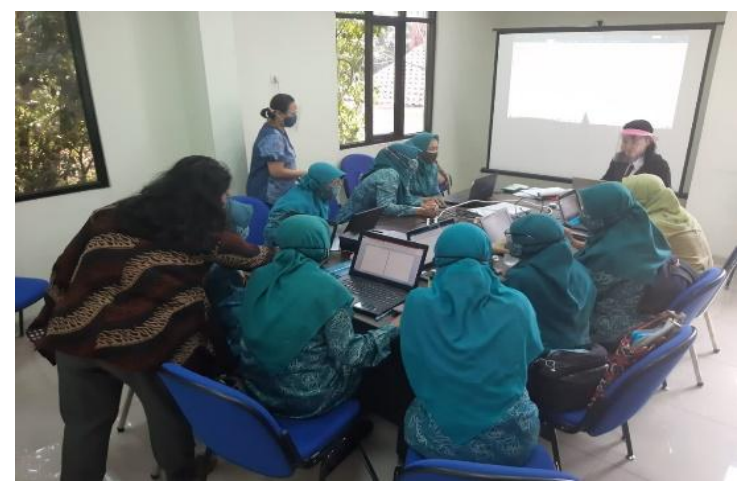

Gambar.5 Kegiatan pendampingan Praktek dan diskusi

Manfaat menerapkan metode Andragogi

1. Dapat menciptakan lingkungan belajar ditandai oleh keadaan fisik yang menyenangkan, saling menghormati dan mempercayai, saling membantu, kebebasan mengemukakan 
pendapat nya, dan setuju adanya perbedaan sehingga peserta merasa nyaman selama proses pembelajaran.

2. Peserta berpartisipasi secara aktif dalam proses belajar karena dengan bantuan fasilitator para kader dapat terbantu dalam belajar dengan bersumber pada pengalaman belajar melalui penggunaan teknik seperti diskusi, permainan peran, kasus dan sejenisnya.

3. Peserta memiliki rasa kemajuan terhadap tujuan belajar mereka dimana dalam kondisi ini para tenaga pengajar dapat membantu peserta untuk mengembangkan dan mengaplikasikan ilmu yang mereka peroleh selama proses pelatihan.

Kegiatan pelatihan Microsoft word dengan menerapkan metode Andragogi yang mengadopsi prinsip RAMP2FAME, telah memberikan implikasi yang besar terhadap keterampilan para kader PKK terutama dalam pembuatan proposal dan laporan yang mengikuti standar dari kelurahan setempat. Diharapkan dengan semakin meningkatnya keterampilan ini para kader PKK akan meningkatkan kualitas layanan kepada masyarakat.

Kegiatan pengabdian ini telah diterima oleh pengurus dan kader PKK Kelurahan Rangkapan Jaya Baru dengan baik dengan baik oleh karena itu tim PKM akan meneruskan kerjasama ini dengan memberikan pelatihan komputer untuk materi yang berbeda seperti pelatihan untuk Microsoft Excel, Power point dan juga pemanfaatan media internet untuk peningkatan wawasan dan juga sebagai sumber penghasilan tambahan yang nantinya dapat disebarluaskan oleh para kader kepada ibu-ibu di wilayah kelurahan rangkapan jaya baru

\section{Simpulan}

Kegiatan pengabdian masyarakat dapat berjalan dengan baik sesuai denga rencana yang telah ditetapkan. Kegiatan pengabdian masyarakat telah mendapatkan sambutan yang baik dari para pengurus dan juga kader PKK. Melalui pelatihan komputer yang dilengkapi dengan metode andragogi yang mengadopsi prinsip Ramp 2 Fame para kader PKK memiliki tingkat keterlibatan yang tinggi, tanggung jawab dan juga memberikan umpan balik, mampu untuk mengembangkan kemampuan, mengembangkan keterampilan, sehingga dalam pelatihan ini para peserta mampu membuat proposal dan laporan sesuai dengan format data posyandu mulai dari membuat desain dari cover proposal dan laporan, membuat penomoran bab dan sub bab otomatis, pemberian nomor halaman berbeda secara otomatis, membuat daftar isi dengan table of content sampai dengan membuat daftar pustaka. Terdapat beberapa saran untuk pengembangan selnajutnya bahwa sebaiknya kegiatan pengabdian masyarakat seperti dapat berkelanjutan serta disebarluaskan kepada kelompok PKK dan Posyandu yang lain di wilayah Depok dan sekitarnya. Memperkaya materi keterampilan komputer yang disesuikan dengan mengikuti kebutuhan di lingkungan PKK dan Posyandu seperti pelatihan Microsoft Office lainnya seperti Excel dan power point.

\section{Ucapan Terima Kasih}

Pada kesempatan ini penulis ingin mengucapkan terima kasih kepada Bapak Zayadi, S.Sos selaku lurah Rangkapan Jaya Baru, Ibu Nurhayati, S.H. selaku Ketua Tim Penggerak PKK Kelurahan Rangkapan Jaya Baru, Ibu Langgeng Sulistyowati dan Ibu Titiek Setyowati selaku Sekretaris, Ibu Yusi Fajarwati selaku Ketua RT 006 Komplek Puri Cinere Hijau, dan Bapak Dr. Deni Mahdiana, S.Kom., MM, M.Kom selaku Dekan Fakultas Teknologi Informasi Universitas Budi Luhur yang telah memberikan izin untuk melaksanakan kegiatan pengabdian 
masyarakat, serta ibu-ibu PKK yang turit berperan aktif dalam mensukseskan kegiatan pengabdian masyarakat ini.

\section{Daftar Pustaka}

Depok, P. (2019). Laporan Tahunan Sekr dan Benhr.

Hani, S. (2016). Penerapan Prinsip Ramp 2 Fame Dalam Meningkatkan Kualitas Belajar Mata Kuliah Analisa Laporan Keuangan Pada Mahasiswa Semester 6 Program Studi Akuntansi Fakultas Ekonomi Umsu. PROSIDING National National Seminar on Accounting and Finance, 393-406.

Hiryanto. (2017). Pedagogi, Andragogi Dan Heutagogi Serta Implikasinya Dalam Pemberdayaan Masyarakat. Dinamika Pendidikan, CCII(1), 65-70.

Jamun, Y. M. (2019). Pelatihan Keterampilan Dasar Komputer dan Teknologi Informasi Bagi Perangkat Desa Pong Lengor, Kecamatan Rahong Utara, Kabupaten Manggarai. Randang Tana Jurnal Pengabdian Masyarakat, 2(2), 146-152.

Nugraha, G. (2013). Penerapan Hasil Belajar Komputer Terapan pada Penyelesaian Tugas Mata Kuliah Dietetika Mahasiswa Pendidikan Tata Boga [Universitas Pendidikan Indonesia]. repository.upi.edu

Rahmawati;Andika Rusli. (2017). Pelatihan Dan Pembimbingan Pembuatan Sistem Laporan Keuangan Sederhana Pada Ukm Di Kota Palopo. Jurnal Akuntansi, 3(1), 35-38.

Saladin, A. (2008). Training. Blogspot. http://training-saladin.blogspot.com/2008/08/prinsipprinsip-andragogy-ramp-2-fame.html

Sulistyanto, H. (2017). Pakom Pelatihan Pengoperasian Komputer Bagi Perangkat Desa Di Kecamatan Gondangrejo Kabupaten Karanganyar. 20(2), 111.

Wanti, L. P., \& Tripustikasari, E. (2018). 78 | Jurnal Pendidikan Nonformal Volume 13, No. 2, September 2018. Madani $\square$ : Indonesian Journal Of Civil Society, 13(2), 78-84.

Windarto. (2017). Model Pembelajaran Cooperative Learning On Project Work. Pustaka Pelajar. http://staffnew.uny.ac.id/upload/131808327/penelitian/1.2 Model Pembelajaran Cooperative Learning on Project Work 2017.pdf 